\title{
Dietary and Socioeconomic Factors Associated with Iron Concentration in Humam Colostrum
}

\author{
Renata M. Gonçalves, José R. Gonçalves \& Nélida S. Fornés
}

Estudo transversal, que objetivou determinar fatores socioeconômicos, de estilo de vida e nutricionais associados ao ferro do colostro de puérperas. Utilizou-se questionário socioeconômico e demográfico para obter características pessoais e de estilo de vida, e outro questionário de frequência de consumo alimentar (QFCA) para avaliação dietética referente aos últimos seis meses de gestação. Coletaram-se amostras de colostro para quantificar o ferro por espectrometria de absorção atômica por chama. Empregou-se estatística descritiva, teste de Mann-Whitney, teste t de Student e coeficiente de correlação de Spearman. A média de ferro de 281,25 $\mu \mathrm{g} / \mathrm{L}$ está compatível com outros estudos, indicando que o colostro é essencial para o bebê nos primeiros meses de vida. Não houve associações significativas entre ferro do colostro e variáveis socioeconômicas e nem correlação com consumo alimentar. Tais fatores não influenciaram o valor do ferro do colostro.

Palavras-chave: absorção atômica; amamentação; ferro.

Descriptive, cross-sectional study which aimed to determine socioeconomic, lifestyle and nutritional values of iron associated with human colostrum. It was used a questionnaire to obtain demographic and socioeconomic characteristics and personal lifestyle, and another Food Frequency Questionnaire (FFQ) for dietary assessment on the last six months of pregnancy. Samples were collected from colostrum to quantify the iron by flame-atomic absorption spectrometry. Descriptive statistics were applied, besides Mann-Whitney test, Student t test and correlation coefficient of Spearman. The average iron $281.25 \mu \mathrm{g} / \mathrm{L}$ is consistent with other studies indicating that the colostrum is essential food for the baby during the first months of life. There were no significant associations between iron colostrum and socioeconomic variables and dietary intake. These factors did not influence the amount of iron obtained from the colostrum.

Keywords: atomic absorption; breastfeeding; iron. 


\section{Introduction}

Micronutrient deficiencies such as iron, vitamin A and iodine are considered large public health problems in many developing countries, causing great damage to health of people ${ }^{1-3}$. These nutrients are important in maintaining vital bodily functions such as growth, reproduction, functions antioxidant and immune ${ }^{2}$.

Among the problems involving micronutrients, the iron deficiency is the most common nutritional deficiencies, especially in childhood, affecting children in the first and second years of life ${ }^{4}$. Studies conducted throughout Brazil showed the prevalence of anemia in children aged 6 months to 5 years, ranging from 36.4\% to $63.0 \%{ }^{5,6}$. In twenty day care centers of São Paulo, the prevalence of anemia was $68.8 \%$ in children aged 6 to 75 months $^{7}$, affecting more than half of the studied population. In the city of Belo Horizonte, the prevalence of anemia among children aged 7 to 74 months was $28.8 \%^{8}$. In a study conducted in the city of Goiânia, the prevalence of anemia among children aged 6 to 24 months was $53.9 \%{ }^{9}$.

During pregnancy, the micronutrient deficience can cause adverse consequences for health of pregnant woman and fetal development. During the lactation period, the nutritional deficiencies of the puerpera may contribute to maintain low nutrient reserves in the infant, increasing the chance of nutritional deficiencies in early life, when there is a higher prevalence of health infantile problems ${ }^{10,11}$, especially when the baby is being fed exclusively via breastfeeding.

It is believed that the needs of nutrient iron in the newborn is mostly covered by the mineral reserves accumulated during fetal development, especially in the third trimester of gestation ${ }^{12}$. In breastfeeding, the concentrations of iron in human milk are considered below is required to satisfy the needs of the baby who needs special attention. It is recommended for babies up to 6 months $0.27 \mathrm{mg}$ of iron daily, based on the consumption of $750 \mathrm{~mL}$ of milk per day, as directed by the Institute of Medicine (IOM) ${ }^{13}$.

Inequalities were observed in the mineral composition of breast milk by Oliveira ${ }^{14}$, noting that the biggest variations to the trace elements occurred in the stage of mature milk, followed by colostrum and after by transition's milk. In all cases, the variations in mineral content are greater than $100 \%$. The variation of iron's concentration on milk results mainly from the assumption that the composition of breast milk depends naturally of the particular nutritional requirements of term baby ${ }^{15}$, demonstrating that even amounts of iron in the colostrum considered low can meet the need of the newborn of each mother.

Therefore, it is important to maintain good nutritional status and health of the pregnant women as a whole, because part of the maternal condition can be transferred to the child via colostrum, which probably depends on the habits of pregnant women and breastfeeding, including food intake. Since the alimentation can provide adequate nutrition to mother and fetus, preventing anemia, for example, investigate the food intake during this phase can help to check whether factors related with the puerpera's lifestyle are related to iron content in colostrum.

Thus, with respect to food intake, some studies have evaluated the retrospective consumption of pregnant adolescents ${ }^{16,17}$ and others have checked the food intake of adult women during pregnancy, compared to postpartum period ${ }^{18}$. But none of these studies attempted to relate food and nutrient intake in the diet with iron levels present in human colostrum. Especially in the Midwest Region of Brazil there are no papers about the subject.

Therefore, knowing that there are few studies in Brazil to assess the dietary intake of women during the reproductive period associated with the quantities of iron from human colostrum awoke us to the need for more work. Moreover are high the prevalence rates in iron deficiency, especially among children, being a public health problem. Having breast milk as the main food source for infants and considering the relevance of iron's colostrum deficiency for the carential prevention of this element, the aims of this study were to determine socioeconomic factors, of lifestyle and nutritionals associated with values of iron in the colostrum of mothers.

\section{Methods}

Cross-sectional descriptive study. The target population studied was comprised of eighty puerperium women hospitalized in rooming in care public Maternity 
Hospital Nossa Senhora de Lourdes from the city of Goiania, Goias State. For convenience sample, was followed those inclusion criteria: maternal age no less than 18 years, mothers with uneventful pregnancy, natural childbirth, term newborn and that has not belonged to risk groups and neither were hospitalized in the Neonatal Intensive Care Unit and those that the colostrum was easily obtained in the first five postpartum days.There was no refusal.

Data were collected between July and December 2008, before the data collection the puerpera became aware of the objectives and procedures of the research and agreed to participate voluntarily, signing the Instrument of Consent. The research protocol number 110/2007 was approved by the Ethics Committee of the Federal University of Goiás.

The data collection occurred through direct interviews and in the presence of the mother and consultation in records by the principal researcher. A socioeconomic and demographic questionnaire was applied, obtaining data such as age, parity, scholarity, income, region lived, use of nutritional supplements, lifestyle information, including alcohol consumption and smoking habits. Were also obtained data from retrospective food intake of the last six months of pregnancy, through semi-quantitative questionnaire that was developed and validated by Fornés et al. ${ }^{19}$, the Food Frequency Questionnaire (FFQ) for use in regional population and low income.

The $\mathrm{FFQ}^{19}$, containing 127 food items, divided into twelve groups (milk and derivatives; legumes, eggs and meat, cereals and derivatives, pasta and snack foods, sugars and sweets, fruits, vegetables, fats, spices and condiments, alcoholic beverages, soft drinks and infusions) with nine frequency categories ${ }^{20}$ of consumption, namely: never or less than 1 time per month, 1 time per month, 2-4 times per month, 2-4 times per week, 5-6 times per week, 1 time per day, 2-3 times per day, 4-5 times per day and six or more times per day. Was calculated the average daily intake of nutrients consumed by the participants through a special program compiled from several composition tables foods ${ }^{21-25}$, to meet the demands of the study.

Subsequent to the interviews, the colostrum samples were obtained by hand milking, proceeding initially the breast sanitize with deionized water. In this procedure were used disposable gloves. The samples corresponded to $10 \mathrm{ml}$ aliquots of colostrum directly placed in sterile polyethylene bottles labeled, previously treated (washed with distilled water, deionized water, nitric acid solution to $5 \%$, and again washed with deionized water). The samples were transported in isothermal box at a temperature of $3^{\circ} \mathrm{C}$ to $4^{\circ} \mathrm{C}$ during the way to the laboratory and frozen at $-20^{\circ} \mathrm{C}$.

The samples preparation for quantitative analysis of the mineral studied consisted of homogenization of colostrum, followed by distribution in aliquots of $0.5 \mathrm{ml}$ in duplicate, as analytical officials standards ${ }^{26}$. The technique used was flame-atomic absorption spectrometry, with equipment Perkin Elmer, brand Aanalyst 200, equipped with System 2 Electrodeless Descharge Lamps (electric discharge lamp - EDL System), of the official laboratory of physicochemical analysis of the National Agricultural Laboratory in Goias, of the Ministry of Agriculture, Livestock and Supply. The detection limit adopted for this factor was $0.005 \mu \mathrm{g} / \mathrm{L}$. For each sample, was used the average calculated from the results of two tests performed.

For the analysis of results took place descriptive statistics of the data. Categorical variables were expressed as frequencies and percentages, the continuous variables, measures of central tendency. Was evaluated the distribution of continuous variables by the Kolmogorov-Smirnov test, considered normal when $\mathrm{p} \geq 0.05$. The comparison of numerical variables with normal distribution according to the respective reference values, was performed by t-Student test. To compare means between two groups, was applied the Mann-Whitney test for nonparametric variables and the Kruskal Wallis test for more than two groups. Was used the Spearman's correlation coefficient to measure the correlation between continuous variables with non-normal distribution. It was established statistical significance level of $5 \%$ in all analysis. The statistical package used for analysis was Statistical Package for Social Sciences (SPSS), version 13.0.

\section{Results}

The eighty postpartum women who participated in the study, 70\% were aged between 18 and 25, and 65\% received up to half of the minimum wage jobs they worked 
at the time. Single mothers were $36.3 \%$ and almost the same percentage had completed primary education as maximum level of scholarity (Table 1). The habits of smoking and alcohol consumption were not common in most cases, at least during the gestation period.

Table 1. Socioeconomic and lifestyle characteristics of the women of the Maternity Nossa Senhora de Lourdes (n= 80). Goiânia, Goiás, 2009.

\begin{tabular}{|c|c|c|}
\hline Participants & $\mathbf{n}$ & $\%$ \\
\hline Total & 80 & 100 \\
\hline \multicolumn{3}{|l|}{ Age (years) } \\
\hline 18 to 25 & 56 & 70,0 \\
\hline 25 to 38 & 24 & 30,0 \\
\hline \multicolumn{3}{|c|}{ Schooling } \\
\hline Primary Education & 28 & 35,0 \\
\hline Secondary Education & 49 & 61,2 \\
\hline Higher Education & 03 & 3,8 \\
\hline \multicolumn{3}{|c|}{ Per capita income (MW') } \\
\hline$<1 / 4$ & 12 & 15,0 \\
\hline $1 / 4$ to $1 / 2$ & 40 & 50,0 \\
\hline $1 / 2$ to 1 & 20 & 25,0 \\
\hline 1 to 2 & 6 & 7,5 \\
\hline No mention & 2 & 2,5 \\
\hline \multicolumn{3}{|c|}{ Marital status } \\
\hline Single & 29 & 36,3 \\
\hline Married & 51 & 63,7 \\
\hline \multicolumn{3}{|c|}{ Smoke habit } \\
\hline Yes & 5 & 6,3 \\
\hline No & 75 & 93,7 \\
\hline \multicolumn{3}{|c|}{ Alcoholic beverage } \\
\hline Yes & 10 & 12,5 \\
\hline No & 70 & 87,5 \\
\hline \multicolumn{3}{|c|}{ Use of nutritional supplements } \\
\hline Yes & 73 & 91,2 \\
\hline No & 7 & 8,8 \\
\hline \multicolumn{3}{|c|}{ Used supplements $^{\mathrm{b}}$} \\
\hline Iron and folic acid & 24 & 30,1 \\
\hline Multivitamin and polimineral & 28 & 35,0 \\
\hline Ferrous sulfate & 21 & 26,1 \\
\hline Not used & 7 & 8,8 \\
\hline
\end{tabular}

${ }^{\text {a }}$ One Minimum Brazilian Wage $=250$ US dollars. ${ }^{\text {b }}$ Supplements reported by participants.
The mothers reported using nutritional supplements during pregnancy in $91.2 \%$ of the samples for at least four months. Of these $35 \%$ made use of multivitamin and polimineral supplements, and $30.1 \%$ said that used the compound based on iron and folic acid together. Had an average of 39 weeks of pregnancy before birth, and an median of two sons of puerperium women. The average of weight of birth infants was 3240.61 g, classified in term newborns.

The iron content found in colostrum samples varied widely from one to the other mothers, with an average of $281.25 \mu \mathrm{g} / \mathrm{L}$, and median $128.94 \mu \mathrm{g} / \mathrm{L}$. Values were above average, considered plausible concentrations of iron in human colostrum, for example, the value obtained from a sample of $1461.35 \mu \mathrm{g} / \mathrm{L}$.

As regards the frequency of food consumption in Table 2 contains the most consumed foods reported by women, expressing those that contributed most to the nutrient values ingested daily, reported in Table 3. Among the foods mentioned by the mothers, who were part of the consumption at least once a day were whole: milk, beef, rice, French bread, crackers, bananas, oranges, lettuce, tomato, margarine, vegetable oil, coffee and soft drinks with sugar. Was perceived that the frequent consumption of foods rich in carbohydrates and proteins, which showed average values above to recommended by the Recommended Dietary Allowances (RDA) ${ }^{27}$, in addition to cholesterol, which is also found in animal products consumed by women during pregnancy in greater quantity. It was observed relevant significance statistical to compare these nutrients with the reference values of literatura ${ }^{27}$.

According to the socioeconomic and lifestyle, women were subdivided into two or more groups to test possible associations with the nine iron quantified the colostrum samples analyzed, according to Table 4 . The results were not statistically significant not only for these examinations, as for the coefficients obtained in the Spearman correlations made between iron levels in colostrum and nutrients (Table 5).

\section{Discussion}

The variation of iron concentration on human milk can be found in this study, which was observed values 
ranging from 0.86 to $4184.00 \mathrm{mg} / \mathrm{L}$. Most of the values obtained showed that the colostrum has considerable quantities of mineral, probably due to diet of the puerperas during pregnancy, mainly from ingested meat products, especially meat and beef liver. The consumption of these products as well as dairy products, eggs and chicken, also contributed to the increase of the protein consumed by pregnant women studied above recommended. Another autor ${ }^{28}$ found wide variation in results obtained for iron, however he have used samples of mature breast milk, which has lower concentrations of some nutrients than the initial milk (colostrum).

The average levels of iron are similar to other researches ${ }^{14,29}$, that have obtained $250 \mu \mathrm{g} / \mathrm{L}$ at $800 \mu \mathrm{g} / \mathrm{L}$, showing variability of results among a sample and other, as observed in this study. They have affirmed ${ }^{29}$ that postpartum iron concentrations in colostrum is not associated with maternal mineral status. This was confirmed in this study, in which there was neither association of iron in colostrum with the fact of the puerpera have used or not nutritional supplements and nor with different types of supplements, based on iron or iron and folic acid, or still Multivitamin and Polimineral compounds.

Another study also showed no significant effect of supplementation during pregnancy on the metal concentrations in human milk. Thus, despite ingesting mineral supplements added to the diet neither the increase of iron intakes and nor the reduction affected the concentrations in human milk in the case of the study mentioned, like found in the analysis of this research with colostrum.

It is observed the same when we tried to correlate the iron with the intake of nutrients in the diet by the puerperas during the gestation period, that difference was not statistically significant. Therefore, although the proteins, carbohydrates, lipids, vitamins $\mathrm{A}$ and $\mathrm{C}$ are found, mostly above the RDA, except the iron that lies beneath, it is confirmed that really the supplementation and the increase of these nutrients intakes not reflect in the concentrations of iron in colostrum. As other authors this is an expected result because the concentrations of iron in human milk does not seem to be influenced by the nutritional iron status of women who breastfeeds ${ }^{29,30,31}$.
Table 2. Frequency of food consumption by women of the Maternity of Our Lady of Lourdes (n=80). Goiânia, Goiás, 2009.

\begin{tabular}{|l|c|c|c|c|c|}
\hline \multirow{2}{*}{ Food } & \multicolumn{5}{|c|}{ Frequency of Food Consumption (\%) } \\
\cline { 2 - 6 } & $\begin{array}{c}\text { Never/ } \\
\text { rare }\end{array}$ & $\begin{array}{c}2-4 \\
\text { times/ } \\
\text { week }\end{array}$ & $\begin{array}{c}5-6 \\
\text { times/ } \\
\text { week }\end{array}$ & $\begin{array}{c}1 \text { time/ } \\
\text { day }\end{array}$ & $\begin{array}{c}2-3 \\
\text { times/ } \\
\text { Day }\end{array}$ \\
\hline Natural milk & 32,5 & 8,8 & 3,8 & 27,5 & 21,3 \\
\hline Yogurt & 18,8 & 28,8 & 2,5 & 11,3 & 3,8 \\
\hline Bean & 1,3 & 2,5 & 3,8 & 10,0 & 82,4 \\
\hline Beef & 5,0 & 53,8 & 5,0 & 7,5 & - \\
\hline Beef liver & 28,8 & 27,5 & 2,5 & 1,3 & - \\
\hline Rice & - & - & - & 3,8 & 96,2 \\
\hline Cassava flour & 28,8 & 27,5 & 1,3 & 16,3 & 2,5 \\
\hline Simple cake & 27,5 & 32,5 & 2,5 & 3,8 & 1,3 \\
\hline Cracker & 18,8 & 31,3 & 10,0 & 21,3 & 2,5 \\
\hline French bread & 15,0 & 31,3 & 6,3 & 41,3 & 3,8 \\
\hline Pasta & 5,0 & 66,3 & 6,3 & 3,8 & 1,3 \\
\hline Sweet(guava) & 41,3 & 15,0 & 2,5 & 3,8 & 1,3 \\
\hline Banana & 18,8 & 26,3 & 7,5 & 35,0 & 1,3 \\
\hline Orange & 2,5 & 48,8 & 12,5 & 26,3 & 1,3 \\
\hline Apple & 15,0 & 38,8 & 8,8 & 20,0 & - \\
\hline Lettuce & 3,8 & 42,5 & 12,5 & 27,5 & 2,5 \\
\hline Boiled potato & 17,5 & 52,5 & 2,5 & 6,3 & - \\
\hline Boiled beet & 27,5 & 45,0 & 3,8 & 2,5 & - \\
\hline Tomato & 2,5 & 32,5 & 13,8 & 46,2 & 5,0 \\
\hline Margarine & 15,0 & 15,0 & 16,3 & 42,5 & 6,3 \\
\hline Vegetable oil & 2,5 & 1,3 & - & 11,3 & 83,8 \\
\hline Coffe & 31,3 & 7,5 & 3,8 & 42,5 & 12,5 \\
\hline Soft drink & 11,3 & 26,3 & 11,3 & 10,0 & - \\
\hline Juice & 31,3 & 31,3 & 8,8 & 16,3 & 3,8 \\
\hline
\end{tabular}

According to recommendation of the Institute of Medicine (IOM) ${ }^{13}$ for babies from birth to six months of age, the newborns of the participants puerperas ingested the amount of $0.21 \mathrm{mg}$ of iron in $750 \mathrm{~mL}$ of milk received daily from the iron average obtained in this study. A value close to the one established as appropriate, that is $0.27 \mathrm{mg} / \mathrm{day}^{13}$. Therefore, despite the needs of the newborn be maintained by iron stored ${ }^{12}$ during the period of development at the pregnancy, the human colostrum studied can meet the daily iron recommendations of the newborn.

It is noteworthy that iron of the colostrum is highly bioavailable in the infant body ${ }^{15}$, and even those 
mothers who did not have values close to the indicated, values constitute the peculiar needs of the children ${ }^{15}$ because each mother produce the milk on ideal proportions of nutrients to meet his children, motive why are explaining the variabilities of concentrations of this mineral. This demonstrates that individual differences of iron in colostrum may therefore be due to the varied needs of each baby. Thus, it is the ideal food for newborns of this mothers.

Table 3. Nutrient intake and association with the recommendations of the women of the Maternity Our Lady of Lourdes. Goiânia, Goiás, 2009.

\begin{tabular}{|c|c|c|c|c|c|c|}
\hline \multirow[b]{2}{*}{ Variables } & \multirow[b]{2}{*}{ Average } & \multirow[b]{2}{*}{ median } & \multirow[b]{2}{*}{ Min. } & \multirow[b]{2}{*}{ Max. } & \multicolumn{2}{|c|}{ Values } \\
\hline & & & & & $\begin{array}{l}\text { Refe- } \\
\text { rence }\end{array}$ & $p^{\mathbf{b}}$ \\
\hline \multicolumn{7}{|c|}{ Macro nutrients } \\
\hline $\begin{array}{l}\text { Energy } \\
\text { (Kcal) }\end{array}$ & 4611,54 & 4462,40 & 2037,07 & 8957,30 & - & - \\
\hline $\begin{array}{l}\text { Carbo- } \\
\text { hydrate } \\
\text { (g) }\end{array}$ & 706,16 & 703,38 & 331,21 & 1328,29 & 175 & $<0,001$ \\
\hline Lipids (g) & 124,47 & 113,49 & 46,92 & 312,34 & - & - \\
\hline $\begin{array}{l}\text { Protein } \\
\text { (g) }\end{array}$ & 165,79 & 157,06 & 72,50 & 337,68 & 60 & $<0,001$ \\
\hline \multicolumn{7}{|c|}{ Micro nutrients } \\
\hline $\begin{array}{l}\text { Calcium } \\
\text { (mg) }\end{array}$ & 1314,33 & 1119,27 & 546,74 & 2988,35 & 1200 & 0,109 \\
\hline Iron (mg) & 24,57 & 24,10 & 9,48 & 62,80 & 30 & $<0,001$ \\
\hline $\begin{array}{l}\text { Retinol } \\
(\mu \mathrm{g})\end{array}$ & 5784,87 & 2562,24 & 401,17 & 32479,94 & 800 & $<0,001$ \\
\hline $\begin{array}{l}\text { Vitamin } \\
\text { C (mg) }\end{array}$ & 439,42 & 388,51 & 81,87 & 1337,19 & 70 & $<0,001$ \\
\hline \multicolumn{7}{|c|}{ Fatty acid } \\
\hline $\begin{array}{l}\text { Satura- } \\
\text { ted (g) }\end{array}$ & 40,35 & 36,31 & 12,43 & 113,59 & - & - \\
\hline $\begin{array}{l}\text { Unsatu- } \\
\text { rated (g) }\end{array}$ & 71,56 & 67,51 & 26,56 & 172,23 & - & - \\
\hline $\begin{array}{c}\text { Choles- } \\
\text { terol } \\
\text { (mg) }\end{array}$ & 521,72 & 380,55 & 101,31 & 1948,76 & - & - \\
\hline
\end{tabular}

+SD = Standard deviation. ${ }^{\mathrm{a}} \mathrm{RDA}$ (NRC, 1989). ${ }^{\mathrm{b}} \mathrm{T}-$-Student test for a sample.

Not only this, but other studies also show that breast milk is best for the newborn child that foods with infant formula using in the preparation cow's integral milk. Even with the fact of cow's milk have a average of iron's value $(0.96 \mathrm{mg} / \mathrm{L})$ higher than human milk, as the value obtained on the study at Goiás state ${ }^{32}$, being that high concentrations of calcium in cow's milk may decrease iron absorption, giving signs of anemia to the baby during the first six months of vida ${ }^{33}$.

Table 4. Iron's colostrum values associated with socioeconomic and lifestyle of the women of the Maternity Our Lady of Lourdes. Goiânia, Goiás, 2009.

\begin{tabular}{|c|c|c|c|c|}
\hline \multirow{2}{*}{ Variable } & \multicolumn{3}{|c|}{ Iron $(\mu \mathrm{g} / \mathrm{L})$} & \multirow{2}{*}{$p$} \\
\hline & Average & Median & CI 95\%+ & \\
\hline \multicolumn{5}{|c|}{ Mother's age } \\
\hline$<20$ years & 2,07 & 1,27 & $0,61-3,53$ & \multirow{2}{*}{$0,987 a$} \\
\hline$\geq 20$ years & 2,89 & 1,17 & $1,27-4,52$ & \\
\hline \multicolumn{5}{|c|}{ Rent } \\
\hline$<1 \mathrm{SM}$ & 189,85 & 129,35 & $58,15-321,54$ & \multirow{3}{*}{$0,706 b$} \\
\hline $\begin{array}{l}1 \mathrm{a}<3 \\
\mathrm{SM}\end{array}$ & 339,53 & 114,10 & $128,84-550,23$ & \\
\hline$\geq 3 \mathrm{SM}$ & 225,40 & 150,99 & $63,88-386,92$ & \\
\hline \multicolumn{5}{|c|}{$\mathrm{N}^{\circ}$ of children } \\
\hline 1 & 2,59 & 1,37 & $1,05-4,14$ & \multirow{2}{*}{$0,981 \mathrm{a}$} \\
\hline 2 or more & 2,77 & 1,16 & $0,77-4,76$ & \\
\hline \multicolumn{5}{|c|}{ Lived in rural zone } \\
\hline Yes & 3,14 & 1,35 & $1,34-4,96$ & \multirow{2}{*}{0,445} \\
\hline No & 1,67 & 1,09 & $0,95-2,40$ & \\
\hline \multicolumn{5}{|c|}{ Contaminated area } \\
\hline Yes & 2,10 & 1,27 & $0,72-3,48$ & \multirow{2}{*}{0,939 a } \\
\hline No & 2,81 & 1,18 & $1,30-4,32$ & \\
\hline \multicolumn{5}{|c|}{ Smoke habit } \\
\hline Yes & 1,14 & 1,38 & $0,31-1,97$ & \multirow{2}{*}{$0,842 \mathrm{a}$} \\
\hline No & 2,79 & 1,18 & $1,45-4,13$ & \\
\hline \multicolumn{5}{|c|}{ Use of alcoholic beverage } \\
\hline Yes & 5,79 & 1,49 & $-3,29-14,80$ & \multirow{2}{*}{$0,206 \mathrm{a}$} \\
\hline No & 2,24 & 1,16 & $1,35-3,13$ & \\
\hline \multicolumn{5}{|c|}{ Use of supplements } \\
\hline Yes & 2,83 & 1,23 & $1,45-4,20$ & \multirow{2}{*}{0,399 a } \\
\hline No & 1,24 & 0,96 & $0,30-2,18$ & \\
\hline \multicolumn{5}{|c|}{ Types of suplements } \\
\hline $\begin{array}{c}\text { Ferrous } \\
\text { sulfate }\end{array}$ & 364,73 & 137,42 & $112,24-617,22$ & \multirow{3}{*}{$0,297 \mathrm{~b}$} \\
\hline $\begin{array}{l}\text { Iron and } \\
\text { folic acid }\end{array}$ & 397,54 & 138,50 & $56,36-738,72$ & \\
\hline $\begin{array}{l}\text { Multivitamin } \\
\text { and } \\
\text { polimineral }\end{array}$ & 158,21 & 108,78 & $95,76-220,66$ & \\
\hline
\end{tabular}

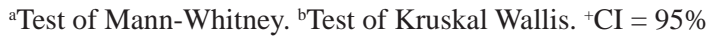
Confidence interval. 
An study found that higher concentrations of hemoglobin were observed among children who were exclusively breastfeeded, followed by those who were predominant breastfeeding pattern ${ }^{34}$, reaffirming the theory that babies fed with breast milk rarely show any sign of anemia. Therefore, there is no clinical or scientific support for the need of extra iron to the newborn, in addition to amounts provided by breast milk of term lactating woman, at least during the first six months.

Table5. Correlation between iron values in colostrum $(\mu \mathrm{g} / \mathrm{L})$ and nutrients of mothers of the Maternity Our Lady of Lourdes. Goiânia, Goiás, 2009.

\begin{tabular}{|c|c|c|}
\hline Variables & $\rho^{\mathbf{a}}$ & $p$ \\
\hline \multicolumn{3}{|c|}{ Macronutrientes } \\
\hline Energy (Kcal) & $-0,007$ & 0,952 \\
\hline Carbohydrate (g) & $-0,068$ & 0,548 \\
\hline Lipids (g) & 0,064 & 0,572 \\
\hline Protein (g) & 0,077 & 0,499 \\
\hline \multicolumn{3}{|c|}{ Micro nutrients } \\
\hline Calcium (mg) & 0,026 & 0,819 \\
\hline Iron (mg) & 0,002 & 0,983 \\
\hline Retinol ( $\mu \mathrm{g})$ & 0,113 & 0,317 \\
\hline Vitamin C (mg) & $-0,031$ & 0,787 \\
\hline \multicolumn{3}{|c|}{ Fatty acid } \\
\hline Saturaded (g) & 0,082 & 0,467 \\
\hline Unsaturated (g) & 0,059 & 0,605 \\
\hline Cholesterol (mg) & 0,117 & 0,301 \\
\hline
\end{tabular}

${ }^{\mathrm{a} C}$ Correlation Coefficient of Spearman.

Regarding income, there was no significant difference associated with the iron, this result was also observed among women in other research ${ }^{35}$. The others factors socioeconomic, demographic and lifestyle tested showed no significant associations. Thus, in agreement with other studies $^{15,29,30,31}$. The concentration of iron in human milk was also did not associate with socioeconomic factors or to maternal nutritional status of iron. Consequently, the social and economic factor of puerpera did not influence on the iron content in colostrum, at least in the way that they were focused and researched.

Thus, in the present study, the factors evaluated were not significantly associated with values of iron, have not been determinative of the concentration of this element in colostrum of puerperas assessed. However, there is evidence that iron levels can be affected in some way due to the variation found in each puerpera and on the different studies compared, which were conducted under various conditions. Because of this variability in the levels of iron in breast milk, it is not recommended to use just the quantification of this mineral to assess the dietetic state of the puerpera and may be searched other likely factors allied with the content of this element.

This proposition refers to several other issues that can justify making further work on the issue in Brazil and other countries to enable comparisons of the results, since this study provides important data as a starting point, confirming that human milk is always the best food for infants in their first months of life, supplying the physiological needs of this phase. Thus, we point out the exclusive breastfeeding like important measure for prevention of anemia and its consequences in childhood.

\section{Acknowledgments}

The Coordination of Improvement of Higher Level Personnel (Capes) by the PhD scholarship awarded to author R. M. Gonçalves. For the Ministry of Agriculture, Livestock and Supply by the logistical support. To the women participants by their availability.

\section{References}

1. Diskhuizen, M. A.; Wieringa, F. T.; West, C. E.

Muherdiyantiningsih M. Concurrent micronutrient deficiencies in lactating mothers and their infants in Indonesia. Am. J. Clin. Nutr. 2001; 73:786-791.

2. Mason, J. B.; Lotfi, M.; Dalmiya, N.; Sethuraman, K.; Deitchler, M. The micronutrient report. Current progress and trends in the control of vitamin A, iodine, and iron deficiencies. Ottawa: The Micronutrient Iniciative; 2001.

3. Ramakrishnan, U. Prevalence of micronutrient malnutrition worldwide. Nutr. Rev. 2002; 60(suppl):46-52.

4. Murila, F. V.; Macharia, W. M.; Wafula, E. M. Iron deficiency anaemia in children of a peri-urban health facility. East. Afr. Med. J. 1999; 76(9):520-523.

5. Brunken, G. S.; Guimarães, L. V.; Fisberg, M. Anemia em crianças menores de três anos que frequentam creches públicas em período integral. J. Pediatr. 2002; 78(1):50-56.

6. Silva, D. G.; Franceschini, S. C. C.; Priore, S. E.; Ribeiro, S. 
M. R.; Szarfarc, S. C.; Souza, S. B. et al. Anemia ferropriva em crianças de 6 a 12 meses atendidas na rede pública de saúde do município de Viçosa, Minas Gerais. Rev. Nutr. 2002; 15:301-308.

7. Bueno, M. B.; Selem, S. S. C.; Arêas, J. A. G.; Fisberg, R. M. Prevalência e fatores associado à anemia entre crianças atendidas em creches públicas de São Paulo. Rev. Bras. Epidemiol. 2006; 9:462-470.

8. Rocha, D. S.; Lamounier, J. A.; Capanema, F. D.; Franceschini, S. C. C. et al. Estado nutricional e prevalência de anemia em crianças que frequentam creches em Belo Horizonte, Minas Gerais. Rev. Paul. Pediatr. 2008; 26(1):6-13.

9. Beraldo, F. C. Ingestão de nutrientes e anemia em crianças de creches municipais em Goiânia [dissertação]. Goiânia, Goiás: Universidade Federal de Goiás; 2008.

10. Canadian Paediatric Society. Nutrition Committee. Nutrient needs and feeding of premature infants. Can. Med. Assoc. J. 1995; 12:1765-1785.

11. Silva, L. S. V.; Thiapó, A. P.; Souza, G. G.; Saunders, C.; Ramalho, A. Micronutrientes na gestação e lactação. Rev. Bras. Saúde Materno Infant. 2007; 7(3):237-244.

12. Donangelo, C. M.; Trugo, N. M. F.; Dorea, J. G. Hepatic reserves of iron, copper and vitamin B12 in Brazilian fetuses and infants of different socioeconomic status. Nutrition 1993; 9:430-436.

13. Institute of Medicine (IOM). National Research Council. Dietary Reference Intakes for vitamin A, vitamin $K$, arsenic, boron, chromium, copper, iodine, iron, manganese, molybdenum, nickel, silicon, vanadium, and zinc. Washington, DC: National Academy Press; 2002.

14. Oliveira, M. C. C. Práticas de amamentação, teores de minerais e vitamina A no leite humano em diferentes fases de lactação segundo variáveis maternas [dissertação]. Belo Horizonte: Universidade Federal de Minas Gerais; 2003.

15. Dorea, J. G. Iron and copper in human milk. Nutrition 2000; 16:209-220.

16. Azevedo, D. V.; Sampaio, H. A. C. Consumo alimentar de gestantes adolescentes atendidas em serviços de assistência pré-natal. Rev. Nutr. 2003; 16:273-280.

17. Barros, D. C.; Pereira, R. A.; Gama, S. G. N.; Leal, M. C. O consumo alimentar de gestantes adolescentes no Município do Rio de Janeiro. Cad. Saúde Pública 2004; 20(suppl 1):121-129.

18. Castro, M. B. T.; Kac, G.; Sichieri, R. Padrão de consumo alimentar em mulheres no pós-parto atendidas em um centro municipal de saúde do Rio de Janeiro, Brasil. Cad Saúde Pública 2006; 22(6):1159-1170.

19. Fornés, N. S.; Stringhini, M. L. F.; Elias, B. M. Reproducibility and validity of a food-frequency questionnaire for use among low-income Brazilian workers. Public Health Nutrition 2003; 6(8):821-827.
20. Fornés, N. S.; Martins, I. S.; Hernan, M.; Velásquez-Meléndez, G.; Ascherio, A. Food frequency consumption and lipoproteins serum levels in the population of Cotia, São Paulo, Brazil. Rev. Saúde Pública 2000; 4(34):380-387.

21. Franco, G. Tabela de composição química dos alimentos. 9. ed. São Paulo: Atheneu; 2003.

22. Ministério do Planejamento e Orçamento. Instituto Brasileiro de Geografia e Estatística - IBGE. Estudo nacional da despesa familiar - ENDEF. Tabelas de composição de alimentos. 4. ed. Rio de Janeiro: IBGE; 1996.

23. Núcleo de Estudos e Pesquisas em Alimentação (NEPA). TACO - Tabela Brasileira de Composição de Alimentos. 2. ed. Campinas: Nepa-Unicamp; 2006.

24. Philippi, S. T. Tabela de composição de alimentos: suporte para decisão nutricional. Brasília: Anvisa, Finatec, NUT-UnB; 2001.

25. Pinheiro, A. B. V.; Lacerda, E. M. A.; Benzecry, E. H.; Gomes, M. C. S.; Costa, V. M. C. Tabela para avaliação de consumo alimentar em medidas caseiras. 4a ed. São Paulo: Atheneu; 2002.

26. Brasil. Ministério da Saúde. Agência Nacional de Vigilância Sanitária. Instituto Adolfo Lutz. Métodos Físico-Químicos para Análise de Alimentos. Brasília: Ministério da Saúde; 2005. 1018 p.

27. National Research Council (NRC). Recommended dietary allowances. 10th ed. Washington, DC: National Academy Press; 1989. 285 p.

28. Morgano, M. A.; Souza, L. A.; Neto, J. M.; Rondó, P. H. C. Composição mineral do leite materno de bancos de leite. Ciênc. Tecnol. Aliment. 2005; 25(4):819-824.

29. Domellöf, M.; Lönnerdal, B.; Dewwey, K.G.; Cohen, R.J.; Hernell, O. Iron, zinc and copper concentrations in breast milk are independent of maternal mineral status. Am. J. Clin. Nutr. 2004; 79:111-115.

30. Zapata, C.V.; Donangelo, C. M.; Trugo, N. M. F. Effect of iron supplementation during lactation on human milk composition. J. Nutr. Biochem. 1994; 5:331-337.

31. Shashiraj, Faridi, M. M.; Singh, O.; Rusia, U. Mother's iron status, breastmilk iron and lactoferrin: are they related? Eur. J. Clin. Nutr. 2006; 60:903-908.

32. Raj, S.; Faridi, M.; Rusia, U.; Singh, O. A prospective study of iron status in exclusively breastfed term infants up to 6 months of age. Int. Breastfeed. J. 2008; 3:3.

33. Gonçalves, J. R.; Mesquita, A. J.; Gonçalves, R. M. Determinação de metais pesados em leite integral bovino pasteurizado no Estado de Goiás. Ci. Anim. Bras. 2008; 9(2):365-374.

34. Oliveira, M. A. A.; Osório, M. M. Consumo de leite de vaca e anemia ferropriva na infância. J. Pediatr. 2005; 81:361-367.

35. . Mello-Neto, J.; Rondó, P. H. C.; Morgano, M. A.; Oshiiwa, M.; Santos, M. L.; Oliveira, J. M. Iron Concentrations in Breast Milk and Selected Maternal Factors of Human Milk Bank Donors. J. Human Lact. 2009; 20(10):1-5. 


\section{Renata M. Gonçalves ${ }^{1 *}$, José R. Gonçalves $^{2} \&$ Nélida S. Fornés ${ }^{3}$}

${ }^{1}$ Faculty of Medicine, Federal University of Goiás, Goiânia, GO. ${ }^{2}$ School of Technology SENAI Roberto Mange and Ministry of Agriculture, Livestock and Supply, Anápolis, GO.

${ }^{3}$ School of Nutrition, Federal University of Goias, Goiânia, GO.

*e-mail: renata.nut@gmail.com 